\title{
Influence of Climatic Conditions \\ on the Traditional Economy \\ of Small-Numbered Indigenous Peoples \\ of Taymyr Dolgano-Nenets Municipal District \\ (the Krasnoyarsk Territory)
}

\author{
Yuliya N. Avdeeva, Kseniya A. Degtyarenko, \\ Natalia N. Pimenova and Vladimir S. Luzan* \\ Siberian Federal University \\ 79 Svobodny, Krasnoyarsk, 660041, Russia
}

Received 14.07.2017, received in revised form 11.08.2017, accepted 22.08.2017

The article presents an attempt to study current methodological and practical approaches to the research of the influence of climatic conditions on the traditional economy of small-numbered indigenous peoples based on Taymyr Dolgano-Nenets Municipal District of the Krasnoyarsk Territory (Krai), as well as present mechanisms of governmental support for the traditional economies of the said peoples.

The authors remark that the analysis of classic and modern works by foreign and Russian researchers shows great interest to climatic changes and consequences of the changes for the indigenous population. At the same time, there is a lack of such researches based on the territory of the Krasnoyarsk Krai, home for many small-numbered indigenous peoples.

At the end of the article the authors draw general conclusions and outline the possible tendencies in the development of traditional economies of small-numbered indigenous peoples, typical for Taymyr Dolgano-Nenets Municipal District of the Krasnoyarsk Territory (Krai) in the modern social and economic environment.

Keywords: climate, small-numbered indigenous peoples, economy, traditional economic management, indigenous environment, culture, government, support.

The reported study was funded by Russian Foundation for Basic Research, Government of Krasnoyarsk Territory, Krasnoyarsk Region Science and Technology Support Fund to the research project No. 17$16-24601$.

DOI: $10.17516 / 1997-1370-0136$.

Research area: culturology.

Introduction. Influence of climatic relevant problems in the globalizing world, where conditions on the traditional economy of small- the whole community is striving to preserve numbered indigenous peoples is one of the most traditional culture and living environment of

(c) Siberian Federal University. All rights reserved

* Corresponding author E-mail address: yulia-avdeeva2406@mail.ru; akseniya.krupkina@mail.ru; vladimir_luzan@list.ru 
such peoples. To a great extent, it is the traditional economies that determine the sophisticated process of preserving traditional culture as an integrated part of the world cultural heritage.

It is especially relevant for the smallnumbered indigenous peoples living in the Far Northern areas of the Russian Federation, for the global warming and active industrial exploration makes a great impact on these territories, imposing its changes into the traditional economy. Moreover, the raw material extractionorientedness of Russian economy suggests that in the short and the long run, industrial exploration of the indigenous environment of the smallnumbered peoples will unwind even more.

For the Krasnoyarsk Territory (Krai) the research of influence of climatic conditions on traditional economy of small-numbered indigenous peoples, especially those resident in Taymyr Dolgano-Nenets Municipal District, is of great strategic relevance for a number of reasons:

1. The Krasnoyarsk Territory (Krai) is home for 8 small-numbered indigenous peoples: the Chulyms, the Keto, the Dolgans, the Selkups, the Nganasans, the Nenets, the Evenki, the Enets. At the same time, representatives of 5 indigenous peoples live in Taymyr DolganoNenets Municipal District, which makes the area especially important in the light of the present research. The quantity of the small-numbered indigenous peoples resident in the territory of Taymyr Dolgano-Nenets Municipal District is 10132 people, i.e. $29.5 \%$ of the total population of the area (Official website of Taymyr DolganoNenets Municipal District), where:

- Dolgans - 5393 people;

- Nenets - 3494 people;

- Nganasans - 747 people;

- Evenki - 266 people;

- Enets - 204 people.

2. In according to the Decree of the Council of Ministers of the USSR No. 12 "On introduction of changes and additions into the List of the regions of the Far North and equated localities, approved by the Decree of the Council of Ministers of the USSR No. 1029 of November 10, 1967" of 03.01.1983, Taymyr Dolgano-Nenets Municipal District belongs to the regions of the Far North (Law assistance system "Consultant Plus"), which suggests special conditions of economy and allowances for the population, and small-numbered indigenous peoples in particular.

3. Severe climatic conditions determining the character of traditional economy. First of all, it is associated with the large geographic extent of the Krasnoyarsk Territory (Krai) in general and Taymyr Dolgano-Nenets Municipal District in particular; the average temperature of January varies from -36 degrees in the North to -18 in the South, and average temperature of July varies from +13 degrees in the North to +25 in the South. Climate of Taymyr Dolgano-Nenets Municipal District is especially severe, with the long winter with strong winds and high humidity. The cool northern summer is very short. Generally speaking, the Taymyr Peninsula hardly experiences any warm periods: the temperature may fall to zero and below practically every day.

The most northern, islandic part of the Taymyr Dolgano-Nenets Municipal District is occupied by ice and arctic deserts. The terrain is hilly and ridgy plain. The tundra and forest tundra zones are 1000-1200 km wide and include the Taymyr Peninsula and the Byrranga mountains.

3. Taymyr Dolgano-Nenets Municipal District is one of the most northern areas of both the Krasnoyarsk Territory (Krai) and the whole country. The northernmost point of Eurasia, Cape Chelyuskin, belongs to its territory. The area includes: the islands of Severnaya Zemlya archipelago, the Taymyr peninsula, the Eastern part of the Gydan Peninsula and the northern part of the Central Siberian Plateau (Official Website of Taymyr Dolgano-Nenets Municipal District ${ }^{1}$ ). 
Consequently, the influence of climatic conditions on traditional economy of small-numbered indigenous peoples, resident in the territory, is very strong due to the geographic peculiarities and extremely low population density, which suggests more individual forms of activity (wild reindeer, fur game and bird hunting, reindeer and fish breeding, collection and processing of velvet antlers and endocrine material), and, therefore, strong dependence on climatic stability.

4. In accordance with the Basic principles of cultural policy of the Russian Federation, approved by the Decree of the President of the Russian Federation No. 808 of 24.12.2014, one of the main tasks of the state is preservation of ethnic cultural tradition, support of folk art and crafts, preservation of ethnocultural diversity as one of the important sources of professional culture and an essential component of ethnonational identity (Law assistance system Consultant Plus). This objective cannot be achieved without relevant measures on preservation of traditional economy of small-numbered indigenous peoples.

5. The territory of Taymyr Dolgano-Nenets Municipal District also includes the sites of major industrial corporations ("Norilsk Nickel" mining and metallurgic company and "RN-Vankor" LLC), that make a significant impact on the local climate and changes in traditional economies.

6. In accordance with the project of the Strategy for social and economic development of the Krasnoyarsk Territory (Krai) (Skhema territorial'nogo planirovaniia Krasnoiarskogo kraia; Proekt Strategii sotsial'noekonomicheskogo...), it is planned to implement a series of investment projects in the area of Taymyr Dolgano-Nenets Municipal District, which may make influence on climatic conditions and traditional economy of the small-numbered indigenous peoples, which are:

- further exploration of oil and gas deposits of the Vankor cluster (Suzunskoe, Tagulskoe,
Lodochnoe) and industrial exploration of the Priangarsky Centre (Kuyumbinskoe, SobinskoPayginskoe, Yurubcheno-Tokhomskoe deposits);

- by the year 2025, the deposits of the East Taymyr oil-and-gas bearing deposits by the Laptev Sea and Khatanga Gulf will have been included into the exploration plan. Exploration of the deposits suggest development of an oil and gas transportation system including a network of pipelines and oil loading terminals, as well as development of Khatanga port;

- development of non-ferrous metallurgy in Taymyr Dolgano-Nenets Municipal District assumes implementation of the development strategy of "Norilsk Nickel" mining and metallurgic company, including exploration of Skalisty mine, modernization of Talnakh Enrichment Plant, exploration of Maslovskoe deposit as well as construction of the mining and metallurgic complex belonging to Russian Platinum Group;

- in the Western part of Taymyr DolganoNenets Municipal District it is planned to explore Syradayskoe deposit of baking coal and create a coke and by-product manufacturing facility;

- to preserve the Northeast Passage, which is a universal task, and to create adequate conditions for the continental arctic shelf survey, it is necessary to develop the ports of Dixon, Khatanga and Dudinka.

Therefore, the factors listed above lead us to the conclusion that the natural and climatic specificity caused by, inter alia, the global warming, as well as the plans of further industrial exploration of the residence area of the smallnumbered indigenous peoples in the territory of Taymyr Dolgano-Nenets Municipal District do make and will continue to make a great impact on the traditional economy of the said peoples.

Research methods. The main theoretical and methodological basis for the research is formed by the works by Russian and foreign 
authors describing the current economic condition of small-numbered indigenous peoples and problems caused by climatic changes, inter alia, in the territories of the Far North of the Russian Federation.

The research is based on the theoretic materials describing possible climate change scenarios and their consequences connected with the large-scale transformation of the environment in the areas of concentrated residence of smallnumbered indigenous peoples, and, therefore, the influence of such changes of the traditional kinds of activities and the traditional economy of the peoples.

Theoretic studies of the influence of climatic conditions on traditional economy of indigenous peoples in Russia and the world as a whole caused wide-scale application of the analyticaldescriptive method that assumes analysis of certain elements and documents with further generalization of the collected data.

The present research actively used such general logical procedures as analysis, synthesis, comparison, drawing analogies, induction, and extrapolation.

Available information. The problems of traditional economies, preservation and development of the traditional lifestyle of today's indigenous peoples are currently studied by Iziumov I.V. (2015), Kharamzin T.G. (2001), Khayrullina N.G. and Popkov Iu.V. (2014).

Moreover, this problem has become a research object not only for individual authors, but also for international organizations. For example, UNESCO Institute for Information Technologies in Education (UNESCO IITE) supported by the Intersectoral platform "UNESCO's contribution to climate change mitigation and adaptation" has developed and opened a new website titled "Climate Change Adaptation: Traditional Knowledge of Indigenous Peoples Inhabiting the Arctic and Far North" on the UNESCO IITE portal. The authors of the project (Bogoslovskaia L.S., Vronskiy N.V., Kniazeva S.Iu., Krupnik I.I., Murashko O.A. et al.) deal with the problems of adaptation to climatic change and influence of the change on traditional lifestyle of small-numbered indigenous peoples of the North.

The issue of adaptation models for indigenous peoples of the Subarctic and the Far North in the situation of climatic change and their influence on the traditional activities of indigenous peoples, as well as issues of organization and performance of the issue-related sociological surveys among Kamchatka small-numbered indigenous peoples is studied by Sharakhmatova V.N. (2014). Adaptation programmes and practices of response to the Arctic climate change are also developed by James D. Ford, Graham McDowell, Julie Jones (2014).

The problem of climatic changes in the Arctic and Subarctic territories have been studied by Megan Sheremata, Leonard J.S. Tsuji, William A. Gough (2016).

From the point of view of global changes in the terrestrial ecosystem of the Arctic tundra, the problem has been developed by Qin Yu, Howard Epstein, Ryan Engstrom, Donald Walker, Mareike Wieczorek, Stefan Kruse, Laura S. Epp (2017), Kolmogorov A., Nikolaev A. and other researchers.

Another interesting work is development and trial of a new method for reconstruction of the past climate and climate change forecasting in the Taymyr peninsula presented by Ukraintseva V.V. (2009) and Pospelov I.N. (2012).

The influence of climatic conditions on the economic activity, surrounding environment and the health condition of the Nenets population of Vaygach island has been studied by the scientists of the Institute of the Environmental Problems of the North of the Ural Branch of RAS, particularly by Davydov A.N., Mikhailova G.V. (2013). The issues of socioeconomic development in the 
situation of global climatic change that has formed special conditions for the maritime activities of the Russian Federation, coastal and maritime territories have become the object for research by Baturova G. and Konovalov A. (2012).

K.P. Whyte and K. Lynn (2013) engaged in the studies of relations between indigenous peoples and the government in the context of adaptation to climatic change in the United States of America, where the indigenous peoples have faced a number of problems, such as loss of economic activities and coastal areas erosion, which caused migration of some communities. According to the researchers, all strata of society (students, activists, environment specialists, scientists, heads of organizations and politicians) need to know how to solve the problems of indigenous peoples associated with climatic change from the global to local level, as well as to be aware of the obstacles that may be caused by oppression (cultural imperialism, deprivation of rights). The researchers come up with sample websites for interaction, consulting and cooperation, and present seven recommendations that demonstrate the value of the measures to be taken by the communities in response to climatic change.

In her research, Marybeth Long Martello (2008) raises the problem of climatic change in the Arctic, where the process is much faster than in other regions of the world, causing serious consequences for indigenous peoples of the Arctic, which also includes Taymyr DolganoNenets Municipal District. The researcher considers the opinions expressed by indigenous peoples of the Arctic, which are especially important in the development and formulation of any statements on the issue.

Dyanna Riedlinger and Fikret Berkes (2001) work on the same problem, emphasizing significance of indigenous peoples of the Canadian Arctic, their unique knowledge of the environment based on extensive experience of working in the coastal area. The researchers study the main areas, where traditional knowledge of indigenous peoples may complete the scientific approach to understanding climatic changes in the Canadian Arctic.

Nancy J. Turner and Helen Clifton (2009) work on the diversity of reaction showed by the British Columbian indigenous peoples to climatic change. On one hand, they study stories and memories of the elders, terms in the languages of indigenous peoples reflecting their reaction to such changes, and on the other hand, they evaluate features of more significant changes in the environment and problems of their sustainability, noticed by indigenous peoples in the modern world (emergence of new phenomena and weather abnormalities, deterioration of forests, meadowlands etc.). Such elements should be taken into account and included into the discussions concerning any global climatic change issues.

F.S. Chapin, G. Peterson, F. Berkes, T.V. Callaghan, P. Angelstam (2004) focus on the Arctic tundra and boreal forest areas that used to be considered as the ultimate borders of the continent due to the vast areas remote from any changes caused by land use and industrial development. Nowadays, the said regions are going through environmental, social and economic changes that happen there just as rapidly as in any other part of the planet. In their article, the scientists generalize the role of the Northern regions in the global system and come up with the factor assessment plan for describing sensitivity of the said territories to social, economic and environmental changes.

S.K. Maharjan (2012), a researcher from Hiroshima University, has studied some climatic risks, vulnerability of certain indigenous communities of Asia to climatic change and their adaptation processes. These communities suffer 
from extreme climatic instability and volatility. To solve climatic problems, they come up with their own adaptation methods and innovations based on traditional knowledge, such as changes of agricultural practices, shifting to other water sources, attracting new invasive species and getting rid of others, decreasing the manufacture of food products being their main source of income. However, the large scale of negative consequences of climatic change causes serious threats to their survival and requires immediate intervention and support from the government.

A.I. Jegede (2016), an African research from Venda University, has been studying the problems of adaptation policy in Africa, environmental and economic consequences of climatic change and their influence on human rights for five years. In particular, the researcher writes of the protection measures provided by the internal legislation to the lands of indigenous peoples as a way of reaction to climatic change.

Therefore, the presented analysis of the available data on the influence of climatic conditions on traditional economy of smallnumbered indigenous peoples proves its urgency as one of the most relevant problems in the globalizing world.

Results. As it has been mentioned above, the major influence on climatic change in the territory of Taymyr Dolgano-Nenets Municipal District of the Krasnoyarsk Territory (Krai), besides global warming, will be associated with the implementation of some investment projects of large oil, gas and metallurgic companies, such as forming of the East Taymyr block of oil and gas extraction centres of the federal level on the basis of the Vankor cluster of deposits, preservation and development of the present industrial potential of non-ferrous metallurgy through implementation of projects by Norilsk Nickel mining and metallurgic company, OJSC, and Russian Platinum Company.
A new promising direction of economic development of Taymyr Dolgano-Nenets Municipal District may be development of valuable coking coals development of the West Taymyr coal area. The hard coal deposits of Taymyr are unique in volume. They are found in three large coal basins: Tungussky, Taymyrsky and Lensky, and reach the volume of 92 billion tons. The potential resources of hydrocarbons of the region constitute around $20 \%$ of all the resources of the Siberian Plateau. By the present moment, 30 oil and gas deposits have been discovered, and three of them are functioning. Moreover, the Taymyr Municipal District is the only has extracting region in the North of the Eastern Siberia. The peninsula is rich in gold; according to the forecast assessment, the Northern province alone holds the amount of gold of several hundred tons. The industrial diamonds deposit discovered in Taymyr possesses over a half of the world's reserve of this mineral (see Official Website of Taymyr Dolgano-Nenets Municipal District).

At the same time, taking the specificity of the territory into account, further economic development of Taymyr Dolgano-Nenets Municipal District should also lead to the development of traditional economic activities of small-numbered indigenous peoples, such as domestic reindeer breeding, hunting, as well as wild reindeer hunting, fur trapping, fishing, and traditional raw material processing.

We cannot ignore that to satisfy the growing needs of Taymyr Dolgano-Nenets Municipal District for electric power and heat, the development of energy infrastructure assumes:

- construction of new energy sources on local energy carriers, including mini-CHPPs on local coal and cogeneration units on hydrocarbon fuel;

- creation of generating capacities in the hydrocarbon extraction sites and extending power transmission lines to remote settlements. 
Consequently, energy infrastructure development may also cause some climatic changes in the territory of the District.

The next years are about to witness transformation of the economically active part of the Krasnoyarsk Territory North, where, besides the traditionally known Norilsk industrial district, the main points of growth will be: the Northern part of Turukhansk District and the Western part of Taymyr Dolgano-Nenets Municipal District as a result of creation of the North-Western centre of oil and gas extraction and development of the Yenisei-Northeast Passage transport corridor; the South of Evenkia as a result of creation of the Angara oil and gas extraction centre; the East of the Taymyr Dolgano-Nenets Municipal District due to exploration of the East Taymyr oil and gas district, development of the Northeast Passage and the port of Khatanga.

At the same time, the Project of Socioeconomic Strategy of the Krasnoyarsk Territory till the year 2030 (Proekt Strategii sotsial'no-ekonomicheskogo...) emphasizes that the policy aimed at support and development of traditional lifestyle and economic activities of small-numbered indigenous peoples will be resumed, for in the situation of active exploration of the natural resources of Taymyr DolganoNenets Municipal District it is the preservation of traditional lifestyle and economic activity that forms the basis for existence of small-numbered peoples as independent ethnic communities.

Along with that, the selected policy of support and development of small-numbered indigenous peoples shall be intended to improve the demographic situation, public health services, raise the level of education and professional training, preservation and research of original cultural heritage, such as languages, traditional kinds of culture, arts and crafts, national kinds of sports.

Under the active exploration of Taymyr Dolgano-Nenets Municipal District, it is necessary to provide well-balanced combination of industrial growth and traditional lifestyle of small-numbered indigenous peoples, minimize environmental harm caused by industrial exploration of hydrocarbon and other mineral deposits, compensate the damage caused to ethnic communities and enterprises by depriving them of the areas of their traditional activities.

In this regard, in order to ensure social and economic development of the territories, protection of the indigenous environment and traditional lifestyle of small-numbered indigenous peoples it has been planned to conclude threeparty agreements between the authorities, mineral developers, social associations or economic subjects of small-numbered indigenous peoples in order to compensate the possible losses and to determine the liabilities of the mineral developers in regard with the present standards of environmental safety and ecosystem rehabilitation in the event of any technogenic catastrophe.

Intensive mineral development in the areas of traditional residence of small-numbered indigenous peoples changes their original habitat and traditional economic activities. As a result, domestic reindeer pasturing areas, as well as migration routes of wild reindeer and birds, go through certain changes; significant areas of reindeer pastures and hunting areas are withdrawn from their traditional use, a part of rivers and water bodies, previously used for fishery, lose their value due to pollution and industrial use.

As a result, to minimize the consequences of the development of the original habitat of small-numbered indigenous peoples, in the year 2013 the state programme of the Krasnoyarsk Territory (Krai) "Creating conditions for the improvement of traditional lifestyle level of small-numbered indigenous peoples of the Krasnoyarsk Territory (Krai)" was approved by 
the Decree of the Government of the Krasnoyarsk Territory No.520-p of 30.11.2013. In accordance with the programme, the total amount of budget assignments for the programme counts 2107237.5 thousand RUR, including:

- 2020685.4 thousand RUR from the regional budget, 86552.1 thousand RUR from the federal budget, including the amounts by years:

- year 2014: 366002.4 thousand RUR, including 353438.6 thousand RUR from the regional budget, 12563.8 thousand RUR from the federal budget;

- year 2015: 432191.7 thousand RUR, including 404186.8 thousand RUR from the regional budget, 28004.9 thousand RUR from the federal budget;

- year 2016: 465674.1 thousand RUR, including 439145.6 thousand RUR from the regional budget, 26528.5 thousand RUR from the federal budget;

- year 2017: 431412.1 thousand RUR, including 411957.2 thousand RUR from the regional budget, 19454.9 thousand RUR from the federal budget;

- year 2018: 411957.2 thousand RUR, including 411957.2 thousand RUR from the regional budget.

Therefore, the presented prospects of exploration of Taymyr Dolgano-Nenets Municipal District open opportunities for forecasting the climatic changes, which, besides the global warming consequences, may make a significant influence on traditional economy of small-numbered indigenous peoples.

Conclusions. The research of the influence of climatic conditions on traditional economy of small-numbered indigenous people's resident in the territory of the Taymyr Dolgano-Nenets Municipal District of the Krasnoyarsk Territory (Krai) draws the following conclusions:

- under current socioeconomic conditions, the most urgent measure to be taken is governmental support in preservation of traditional economic activities of smallnumbered indigenous peoples, as without such support (legal, organizational, infrastructural, financial, material) preservation of traditional economic activities is hardly possible;

- attractiveness of the climate of nonnorthern territories leads to the migration of small-numbered indigenous peoples from their ethnic settlements, termination of their traditional lifestyle and traditional economic activities;

- as Taymyr Dolgano-Nenets Municipal District is one of the least geologically studied regions of Russia (only $2 \%$ of its mineral resources have been explored), we may foresee further climatic change caused by anthropogenic factors, such as natural reserve extraction, which has been described above;

- it is necessary to improve the quality of medical service in the areas of traditional residence and economic activity of smallnumbered indigenous peoples, to develop distant and mobile means of consulting and medical examination;

- it is necessary to improve the system of children's education, including development of online study modes, equipping educational institutions and remote settlements with distance learning gear;

- it is necessary to take some measures for the development of ethnic literature, visual art, traditional crafts of small-numbered indigenous peoples;

- it is necessary to provide smallnumbered indigenous peoples with access to modern information and telecommunication services;

- it is necessary to introduce a system of grants, institutions of sponsorship and philanthropism and other means of financing projects intended to develop traditional economic activities; 
- it is required to develop traditional economic activities ensuring occupation of small-numbered indigenous peoples by means of mobilization of internal resources of households and communities, as well as through some measures of governmental support, support from commercial and non-commercial organizations, including introduction of a system for centralized procurement of traditional products of smallnumbered indigenous peoples' economic activities;
- it is required to conclude trilateral agreements between the authorities, mineral developers, social associations or economic subjects of small-numbered indigenous peoples in order to compensate the possible losses and to outline the liabilities of the mineral developers concerning following the approved environmental safety standards and carrying out ecosystem rehabilitation in the event of a technogenic catastrophe.

Official Website of Taymyr Dolgano-Nenets Municipal District. Available at: http://www.taimyr24.ru/

\section{References}

Adaptatsiia k izmeneniiam klimata: traditsionnye znaniia korennykh narodov Arktiki i Kraynego Severa [Adaptation to climatic changes: traditional knowledge of indigenous peoples of the Arctic and the Far North]. Available at: http://ru.iite.unesco.org/courses/climate_change/index.html.

Baturova, G., Konovalov, A. (2012). Teplo idet na sever [The heat is going north], In Morskie vesti Rossii [Russian Maritime News], 3.

Burykin, A.A. (2002). Nekotorye problemy sotsiokul'turnogo razvitiia malochislennykh narodov Severa RF v svete gendernogo podkhoda [Some problems of sociocultural development of smallnumbered peoples of the RF North in the light of gender approach], In Rasy i narody [Races and peoples], 28, 188-213.

Chapin, F.S., Peterson, G., Berkes, F., Callaghan, T.V., Angelstam, P. (2004). Resilience and Vulnerability of Northern Regions to Social and Environmental Change. A Journal of the Human Environment, 33(6), 344-349.

Davydov, A.N., Mikhaylova, G.V. (2013). Izmenenie klimata i usloviia zhizni v Arktike $\mathrm{v}$ vospriiatii nentsev ostrova Vaygach [Climatic changes and life conditions in the Arctic through the eyes of the Nenets from Vaygach island], In Ekologiia cheloveka [Human ecology], 2, 29-34.

Ford, J., McDowell, G., Jones J. (2014). The state of climate change adaptation in the Arctic. Environmental Research Letters, 9 (10).

Jegede A.O. (2016). The environmental and economic implications of the climate change and extractive industry nexus in Africa. Environmental Economics, 7 (4-1), 95-103.

Iziumov, I.V., Kharamzin, T.G. (2015). Ekonomika traditsionnogo prirodopol'zovaniia korennykh narodov Severa: teoreticheskie aspekty razvitiia [Economy of traditional nature use of indigenous peoples of the North: theoretical aspects of development], In Fundamental'nye issledovaniia [Fundamental research] 12-5, 1024-1027.

Chelovecheskiy kapital Krasnoiarskogo kraia: Forsayt-issledovanie-2030: analiticheskiy doklad [Human capital of the Krasnoyarsk Territory (Krai): Foresight research-2030: analytic report] (2010). Krasnoyarsk, SibFU. 126 p.

Constitution of the Russian Federation. Law assistance system Consultant Plus. 
Kharamzin, T.G. (2001). Ekonomika traditsionnogo prirodopol'zovaniia korennykh malochislennykh narodov Severa (po materialam sotsiologicheskikh issledovaniy) [Economics of traditional nature use of small-numbered indigenous peoples of the North (based on sociological surveys)]. Moscow, Ikar.

Korennye malochislennye narody Taymyra: traditsii, byt, kul'tura: rekomendatel'nyy ukazatel' literatury [Small-numbered indigenous peoples of Taymyr: traditions, lifestyle, culture: recommended literature] (2005). Dudinka, 287 p.

Koptseva, N.P. (2014). Expert analysis of the main trends of Northern Siberia's indigenous smallnumbered peoples economic development. In Economic Annals-XXI, 11-12, 93-96.

Koptseva, N.P., Kirko, V.I. (2014a). Information basis for formation of positive ethnic identities in the process of acculturation of indigenous peoples of the Arctic Siberia (Krasnoyarsk, Russia). In Life Sci J, 11(8), p479-483.

Koptseva, N.P., Kirko, V.I. (2014b). Processes of acculturation the Khakass (indigenous people of Southern Siberia), living outside Khakassia in urban and students environment. In American Journal of Applied Sciences, 11 (12), 1969-1975.

Koptseva, N.P., Reznikova, K.V. (2015). Refinement of the causes of ethnic migration North Selkups based on the historical memory of indigenous ethnic groups Turukhansk district of Krasnoyarsk Krai. In Bylye gody, 4 (38), 1028-1038.

Krivonogov, V.P. (2008). Tofalary: tri shaga v buduschee [The Tofalars: three steps into the future], Krasnoyarsk: KSPU named after V.P. Astafiev. 197 p.

Libakova, N.M., Sitnikova, A.A., Sertakova, E.A., Kolesnik, M.A., Ilbeykina, M.I. (2014). Interaction of the Yakut ethnicity and biological systems in the territory of the Sakha Republic (Hordogoy settlement, Suntarsky District) and Krasnoyarsk Krai (Essey settlement, Evenks District). In Life Sci J, 11 (6s), 585-592.

Long Martello, M. (2008). Arctic indigenous peoples as representations and representatives of climate change. In Social Studies of Science, 38(3), 351-376.

Maharjan, S.K. (2012). Climate risks, vulnerabilities and climate change adaptation practices in selected indigenous communities in Asia. Sixth international conference on community-based adaptation, Hanoi, Vietnam.

Osnovy gosudarstvennoy kul'turnoy politiki Rossiyskoy Federatsii, utverzhdionnye Ukazom Prezidenta Rossiyskoy Federatsii ot 24.12.2014 No. 808 [Principles of state cultural policy of the Russian Federation, approved by the Decree of the President of the Russian Federation No. 808 of 24.12.2014] Available at: http://mkrf.ru/upload/mkrf/mkdocs2016/OSNOVIPRINT.NEW.indd.pdf

Official Website of the Taymyr Dolgano-Nenets Municipal District. Available at: http://www. taimyr24.ru/

Official portal of the Krasnoyarsk Territory (Krai). Available at: http://www.krskstate.ru

Popkov, Iu.V. (2014). Korennye narody Severa v usloviiakh globalizatsii [Indigenous peoples of the North under the conditions of globalization], In Zhurnal'nyy klub Intelros "Vek globalizatsii" [Intelros Magazine Club “Globalization Age”], 1.

Pospelov, I.N., Ukraintseva, V.V. (2012). O novom kompleksnom metode rekonstruktsii klimatov i prognozirovanii klimaticheskikh izmeneniy $\mathrm{v}$ buduschem [On the new integrated method of climate 
reconstruction and future climatic change forecasting], In Obschestvo. Sreda. Razvitie (Terra Humana) [Society. Environment. Development (Terra Humana)], 3, 216-222.

Postanovlenie Pravitel'stva Krasnoiarskogo kraia ot 30 sentiabria 2013 g. No. 520-p "Ob utverzhdenii gosudarstvennoy programmy Krasnoiarskogo Kraia "Sozdanie usloviy dlia povysheniia urovnia traditsionnogo obraza zhizni korennykh malochislennykh narodov Krasnoiarskogo kraia" [Decree of the Government of the Krasnoyarsk Territory (Krai) No. 520-p "On approval of the state programme of the Krasnoyarsk Territory (Krai) "Creating conditions for the improvement of the traditional lifestyle standards of small-numbered indigenous peoples of the Krasnoyarsk Territory (Krai)" of September 30, 2013”]. Law assistance system Consultant Plus.

Postanovlenie Soveta Ministrov SSSR ot 03.01.1983 No. 12 "O vnesenii izmeneniy i dopolneniy $v$ Perechen' rayonov Kraynego Severa i mestnostey, priravnennykh k rayonam Kraynego Severa, utverzhdennyy Postanovleniem Soveta Ministrov SSSR ot 10 noiabria 1967 g. No. 1029” [Decree of the Council of Ministers of the USSR No. 12 "On introduction of changes and additions into the List of the regions of the Far North and equated localities, approved by the Decree of the Council of Ministers of the USSR No. 1029 of November 10, 1967" of 03.01.1983]. Law assistance system Consultant Plus.

Proekt Strategii sotsial'no-ekonomicheskogo razvitiia Krasnoiarskogo kraia do 2030 goda [Project of socioeconomic development strategy of the Krasnoyarsk Territory till the year 2030]. Available at: http://www.krskstate.ru/2030/plan

Riedlinger, D, Berkes, F. (2001). Contributions of traditional knowledge to understanding climate change in the Canadian Arctic. In Polar Record, 37 (203), 315-328.

Sharakhmatova, V.N. (2014). Adaptatsii k izmeneniiam klimata i znachenie traditsionnykh znaniy korennykh narodov Severa v mezhdunarodnykh proektakh I peregovornykh protsessakh [Adaptation for climatic change and significance of the traditional knowledge of indigenous peoples of the North in international projects and negotiation processes], In "Na perekrestke kontinentov": materialy XXXI chteniy Krasheninnikova ["On the junction of continents": Proceedings of the XXXI Krasheninnikov readings]. Petropavlovsk-Kamchatsky, 363-370.

Sheremata, M., Tsuji, L., Gough, W.A. (2016). Collaborative Uses of Geospatial Technology to Support Climate Change Adaptation in Indigenous Communities of the Circumpolar North. Geospatial Technology. In Environmental and Social Applications, 197-215.

Skhema territorial'nogo planirovaniia Krasnoiarskogo kraia [Territorial planning layout of the Krasnoyarsk Territory (Krai)]. Available at: www.urbanistika.ru

Turner, N., Clifton H. (2009). "It's so different today": Climate change and indigenous lifeways in British Columbia, Canada. In Global Environmental Change, 19 (2), 180-190.

Ukraintseva, V.V. (2009). Klimat poluostrova Taymyr v golotsene i prognoz izmeneniia klimata v Rossiyskoy chasti Arktiki. Geologiia poliarnykh oblastey Zemli [Taymyr climate in holocoen and climatic change forecast for the Russian part of the Arctic. Geology of the Polar areas of the Earth], In Proceedings of the XLII Tectonic Conference, 2, 250-251.

Qin Yu, Epstein, H., Engstrom, R., Walker, D. (2017). Circumpolar arctic tundra biomass and productivity dynamics in response to projected climate change and herbivory. Global Change Biology.

Whyte K.P., Lynn K. (2013). Indigenous peoples, climate change and the government-togovernment relationship. In SSRN Electronic Journal. 
Zamarayeva, Y.S., Kistova, A.V., Pimenova, N.N., Seredkina, N.N. (2015). Taymyr reindeer herding as a branch of the economy and a fundamental social identification practice for indigenous peoples of the Siberian Arctic. In Mediterranean Journal of Social Sciences, 6 (3), 225-232.

\section{Влияние климатических условий на традиционную экономику коренных малочисленных народов, проживающих в Таймырском Долгано-Ненецком муниципальном районе (Красноярский край)}

Ю.Н. Авдеева, К.А. Дегтяренко, Н.Н. Пименова, В.С. Лузан Сибирский федеральный университет Россия, 660041, Красноярск, пр. Свободный, 79

В статье предпринята попытка раскрыть актуальные методологические и практические подходы к исследованию влияния климатических условий на традиционную экономику коренных малочисленных народов на примере Таймырского Долгано-Ненеикого мунииипального района Красноярского края, а также действующие механизмы государственной поддержки традиционных способов хозяйствования данных народов.

В статье отмечено, что анализ классических и современных зарубежных и отечественных исследований данного предмета выявляет большой интерес со стороны авторов к проблеме изменения климата и последствий данных изменений для аборигенного населения в иелом. $B$ то же время можно зафиксировать дефицит аналогичных исследований относительно территорий Красноярского края, где проживают коренные малочисленные народы.

В заключение авторами обозначены общие выводы и вероятные тенденции развития традиционных способов хозяйствования коренных малочисленных народов, характерных для Таймырского Долгано-Ненечкого мунииипального района Красноярского края, в современных соииально-экономических условиях.

Ключевые слова: климат, коренные малочисленные народы, экономика, традиционные формы хозяйствования, исконная среда обитания, культура, государство, поддержка.

Исследование выполнено при финансовой поддержке Российского фонда фундаментальных исследований, Правительства Красноярского края, Красноярского краевого фонда поддержки научной и научно-технической деятельности в рамках научного проекта № 17-16-24601.

Научная специальность: 24.00.00 - культурология. 